\title{
Comparative Evaluation of Two Hyaluronic Acid Gel Products for the Treatment of Interdental Papillary Defects
}

\section{Usporedna procjena dvaju gelova s hijaluronskom kiselinom za liječenje interdentalnih papilarnih defekata}

\footnotetext{
${ }^{1}$ University of Pécs, Medical School, Department of Dentistry, Oral and Maxillofacial Surgery, Pécs, Hungary

Sveučilište Pécs, Medicinski fakultet, Zavod za oralnu i maksilofacijalnu kirurgiju, Pécs, Mađarska

2 Semmelweis University, Faculty of Dentistry, Department of Oral Biology, Budapest, Hungary

Zavod za oralnu biologiju Fakulteta dentalne medicine Sveučilišta Semmelweis, Budimpešta, Mađarska
}

\section{Abstract}

Objectives: The aim was to investigate the efficacy of single injections of two different hyaluronic acid products, Flex Barrier and Revident, in reducing the size of black triangles to treat Nordland-Tarnow Class I and II recessions. Material and Methods: Forty adult patients were recruited with at least two upper and two lower interdental papilla defects in the front region between canine teeth. According to the Nordland-Tarnow classification of papillary defects, both Class I and Class II recessions were included in the investigation. Patients were randomly assigned to experimental groups to receive single injections of two different hyaluronic acid products, either Flex Barrier or Revident. The untreated sites served as controls. Photographs were taken before and immediately after the treatment, and again after one week and one month. To determine the size of the black triangles, Image I software was used. For statistical analysis, a mixed-design ANOVA was applied. Results: Both Flex Barrier and Revident significantly decreased the size of the treated defects immediately after the treatment and also one week later $(p<0.001)$. The beneficial effect of Revident lasted longer than Flex Barrier as it remained significant even after one month in Revident-treated patients, however, not in the Flex Barrier-treated group. Furthermore, Nordland-Tarnow Class I lesions generally showed a greater improvement than Class II lesions. Conclusion: In this proof-of-concept, randomized clinical trial we have demonstrated the clinical applicability of both Flex Barrier and Revident, although Revident gave longer-lasting improvements than Flex Barrier. Further trials are needed to optimize multiple-application protocols for treating gingival black triangles.
Received: February 18, 2020

Accepted: June 28, 2020

Address for correspondence

Gábor Varga

Semmelweis University

Faculty of Dentistry

Department of Oral Biology

Budapest, Hungary

varga.gabor@dent.semmelweis-univ.hu

\section{Key words}

Gingival Recession; Interdental Papilla; Hyaluronic Acid

\section{Introduction}

Anterior esthetics has become one of the most important topics in contemporary dentistry (1). While several sophisticated techniques exist to create "white esthetics", the successful restoration of "pink esthetics" remains a challenge for clinicians, especially in the interdental area (2).

The formation of a "black triangle" between teeth due to the absence of sufficient papilla may result from several factors, including age, periodontal disease, crown form and the course of the cemento-enamel junction. It appears because of the increased distance between the contact point and the alveolar bone crest (3-5). The prevalence of open embrasure areas appears to be relatively high, affecting $38 \%$ of adult orthodontic patients and $15 \%$ of the general adolescent population (6).

Various treatment approaches have been developed in recent years to treat interdental papilla loss, including surgical techniques (7), tissue engineering methods, such as the use of an injectable regenerative acellular dermal matrix (8), and autologous fibroblast injections (9). A non-surgical method
Uvod

Estetika prednjih zuba postala je jedna od najvažnijih tema suvremene dentalne medicine (1). Iako se primjenjuje nekoliko sofisticiranih tehnika za stvaranje bijele estetike, uspješna obnova ružičaste estetike i dalje ostaje izazov za kliničare, posebno u interdentalnom području (2).

Pojava crnog trokuta između zuba zbog nedovoljne visine papile može biti rezultat nekoliko čimbenika, uključujući dob, parodontnu bolest, oblik krunice i tijek cementno-caklinskog spoja. Pojavljuje se kao rezultat povećanog razmaka između dodirne točke i grebena alveolarne kosti $(3-5)$. Čini se da je prevalencija otvorenih interdentalnih područja razmjerno visoka, što utječe na $38 \%$ odraslih ortodontskih pacijenata i $15 \%$ opće populacije adolescenata (6).

Posljednjih godina pojavili su različiti pristupi u liječenju gubitka interdentalne papile, uključujući kiruršku tehniku (7), metodu tkivnog inženjerstva poput uporabe injekcijskog regenerativnog acelularnog dermalnog matriksa (8) i autolognih injekcija fibroblasta (9). Nedavno uvedena meto- 
introduced recently is the injection of hyaluronic acid fillers into the deficient papillae. The technique was first described by Becker et al. (10) in a pilot study treating 14 sites in 11 patients. Several other reports followed that work (11-14). Those studies reported variable outcomes with differing success rates, which are difficult to compare due to the lack of appropriate control sites and the different number of treatment sessions per individual.

In the present proof-of-concept study the two different hyaluronic acid preparations were used, Flex Barrier and Revident, as detailed below in Methods. Both gels were specifically developed for human clinical periodontal applications, including papilla reconstruction to correct "black triangles" in the interdental area. According to the manufacturers' documentation, both Flex Barrier and Revident are bacteriostatic, antiseptic and promote wound healing, but neither of them was previously tested for their effectiveness in randomized clinical trials. Our study aimed to investigate the efficacy of the two different hyaluronic acid products in a randomized controlled clinical trial examining the effect of a single administration of injectable hyaluronic acid gel on the size of "black triangles" for the treatment of the Nordland-Tarnow class I and II recessions (15).

\section{Material and methods}

We investigated the effects of the two hyaluronic acid gel products; both were compared to the untreated control papillae at four consecutive measurement time points. Based on a sample-size calculation using $G^{*}$ Power 3.1.9.7 software (Dusseldorf, Germany), the total number of papillae to be investigated for each hyaluronic acid group was 76 for an alpha of 0.05 , a power of 0.90 , an effect size of 0.3 (comparing the treated papillae to the untreated controls) and a correlation among the repeated measures of 0.5 . For each patient, we aimed to treat at least one upper and one lower papilla and investigate at least one upper and one lower control papilla (at least 4 papillae/patient). Therefore, a minimum of 19 patients was needed for each hyaluronic acid group. In order to compensate for the loss to follow-up, we enrolled more patients and treated more papillae per patient. A total of 40 adult patients were involved (30 females and 10 males) with an average age of $44.4( \pm 12.8$; inclusion criterion: age between 18-70), who had at least two upper and two lower interdental papillary defects in the front region between canine teeth. According to the Nordland-Tarnow classification of papillary defects, Class I or Class II recessions were included in the investigation.

Exclusion criteria were:

- active periodontitis (Community Periodontal Index (CPI) grade 3 or 4 ),

- acute oral and/or upper respiratory tract infection,

- previous surgical treatment of the papillae to be investigated (due to the presence of scar tissue),

- pregnancy or lactation,

- smoking,

- bleeding disorders or any medication that would affect blood coagulation (e.g.: coumarin-type drugs, platelet aggregation inhibitors, etc.), da jest ubrizgavanje punila s hijaluronskom kiselinom u papile s defektom. Tehniku su prvi opisali Becker i suradnici (10) u pilot-studiji u kojoj je tretirano 14 mjesta kod 11 pacijenata. Nakon tog rada slijedilo je nekoliko drugih izvještaja (11 - 14). U tim su studijama autori izvijestili o različitim ishodima $s$ različitim postotcima uspjeha koje je teško usporediti zbog nedostatka odgovarajućih kontrolnih mjesta i različitog broja posjeta tijekom liječenja po pojedincu.

U ovom istraživanju koncepta dokazivanjem korištena su dva različita pripravka hijaluronske kiseline - Flex Barrier i Revident, kao što je detaljnije opisano u dijelu teksta o materijalima i metodama. Oba su gela posebno razvijena za kliničku parodontološku primjenu na ljudima, uključujući rekonstrukciju papile za ispravljanje crnih trokuta u interdentalnom području. Prema dokumentaciji proizvođača i Flex Barrier i Revident su bakteriostatski, antiseptički i potiču zarastanje rana, ali ni jednomu nije testirana učinkovitost u randomiziranim kliničkim ispitivanjima. Naša studija imala je za cilj ispitati učinkovitost dvaju različitih proizvoda s hijaluronskom kiselinom u randomiziranom kontroliranom kliničkom ispitivanju analizom učinka jedne primjene injekcijskoga gela s hijaluronskom kiselinom na veličinu crnih trokuta za liječenje Nordland-Tarnowe klase I. i II. recesije (15).

\section{Materijali i metode}

Istražili smo učinke dvaju gelova s hijaluronskom kiselinom; oba su uspoređena s neinjektiranim kontrolnim papilama u četirima uzastopnim vremenskom točkama mjerenja. Na temelju izračuna veličine uzorka softverom $G^{*}$ Power 3.1.9.7 (Düsseldorf, Njemačka) ukupni broj papila koje se ispituju za svaku skupinu korištene hijaluronske kiseline iznosio je 76 za alfa od 0,05 , snaga je bila 0,90 , efektivna veličina od 0,3 (uspoređujući tretirane papile s netretiranim kontrolama) i korelacija između ponovljenih mjera na 0,5 . Svakom smo pacijentu nastojali liječiti barem jednu gornju i jednu donju papilu te istražiti barem jednu gornju i jednu donju kontrolnu papilu (najmanje 4 papile/pacijenta). Stoga je bilo potrebno najmanje 19 pacijenata za svaku skupinu pojedine hijaluronske kiseline. Kako bismo nadoknadili gubitak koji se dogodio nakon praćenja, upisali smo više pacijenata i liječili više papila po pacijentu. Ukupno je bilo uključeno 40 odraslih pacijenata (30 žena i 10 muškaraca) prosječne dobi od 44,4 godine $( \pm 12,8)$ (kriterij za uključivanje: dob između 18 - 70) koji su imali barem dva gornja i dva donja interdentalna papilarna oštećenja u prednjoj regiji između psećih zuba. Prema klasifikaciji Nordland-Tarnowih papilarnih oštećenja, u ispitivanje su uključene recesije klase I ili II.

Kriteriji za isključivanje bili su:

- aktivni parodontitis (indeks parodontnog indeksa u zajednici - CPI, stupanj 3 ili 4)

- akutna infekcija oralnoga tkiva i/ili gornjega dišnog trakta,

- prethodno kirurško zahvaćanje papile koja nas zanima (prisutnost ožiljnog tkiva)

- trudnoća ili dojenje

pušenje

poremećaji u krvarenju ili bilo koji lijekovi koji bi mogli utjecati na zgrušavanje krvi (npr., medikamenti poput kumarina, inhibitora agregacije trombocita itd.) 
- systemic diseases that may affect periodontal health (e.g.: diabetes mellitus) or any kind of ongoing immunosuppression,

known or suspected allergy to local anesthetics and/or hyaluronic acid.

All the patients underwent non-surgical periodontal therapy three-six months prior to the present investigation. As a baseline examination, a CPI chart of the front teeth was recorded and digital photographs were taken in frontal and lateral views, centered to central incisors and lateral incisors, respectively. Camera settings were standardized (1:3 aspect ratio, Canon EOS 550D camera, Canon EF $100 \mathrm{~mm}$ f $/ 2.8$ Macro USM lens, manual mode, $1 / 200 \mathrm{sec}, \mathrm{f} / 22$, ISO 100 , Sigma EM-140 DG ring flash, manual mode, $1 / 2$ power; the optical axis is parallel to the occlusal plane). Papillary defects were visually classified according to the criteria of the Nordland-Tarnow classification, following examiner calibration.

Two different hyaluronic acid preparations were used. As a reference material, the commercially available Flex Barrier gel (Naturelize GmbH and Bio Science GmbH, RansbachBaumbach, Germany) was purchased. Flex Barrier was specifically developed for clinical periodontal applications, including papilla reconstruction to correct "black triangles" in the interdental area (16). According to the manufacturer's description, it is a safe, synthetic, and user-friendly alternative to resorbable membranes, and is bacteriostatic and antiseptic, and it promotes wound healing. The gel contains two-thirds cross-linked and one-third non-cross-linked hyaluronic acid. Since the two types of particle vary in size, they compress and form a flexible membrane on the area to be shielded. The barrier function remains active for three weeks (16). sistemske bolesti koje mogu utjecati na parodontno zdravlje (npr., dijabetes melitus) ili bilo koja vrstu terapijske imunosupresije

poznata alergija ili sumnja na lokalne anestetike i/ili hijaluronsku kiselinu.

Svi pacijenti podvrgnuti su nekirurškoj inicijalnoj parodontnoj terapiji od 3 do 6 mjeseci prije početka studije. Kao temeljni podatak zabilježen je CPI graf prednjih zuba i snimljene su digitalne fotografije u prednjem i bočnom prikazu sa središnjim sjekutićima u vidnom polju. Postavke kamere bile su standardizirane (proporcija 1: 3, Canon EOS 550D kamera, Canon EF 100 mm f/2,8 makro USM objektiv, ručni način rada, 1/200 sekunda, f/ 22, ISO 100, Sigma EM140 DG bljeskalica, priručnik način rada, $1 / 2$ snage; optička os paralelna s okluzalnom ravninom). Nedostatci papila vizualno su klasificirani prema kriterijima Nordland-Tarnowe klasifikacije, nakon kalibracije ispitivača.

Korištena su dva različita pripravka s hijaluronskom kiselinom. Kao referentni materijal kupljen je komercijalno dostupan gel Flex Barrier (Naturelize GmbH i Bio Science GmbH, Ransbach-Baumbach, Njemačka). Flex Barrier posebno je razvijen za kliničku parodontnu primjenu, uključujući rekonstrukciju papile za ispravljanje crnih trokuta u interdentalnom području (16). Prema opisu proizvođača, sigurna je, sintetička i korisna alternativa resorbirajućim membranama, bakteriostatska je i antiseptička te potiče zarastanje rana. Gel sadržava dvije trećine križno umrežene hijaluronske kiseline i jednu trećinu neumrežene. Budući da se dvije vrste čestica razlikuju po veličini, one se zbog pritiska raspoređuju i tvore fleksibilnu membranu na području koje treba zaštititi. Funkcija barijere ostaje aktivna tri tjedna (16).

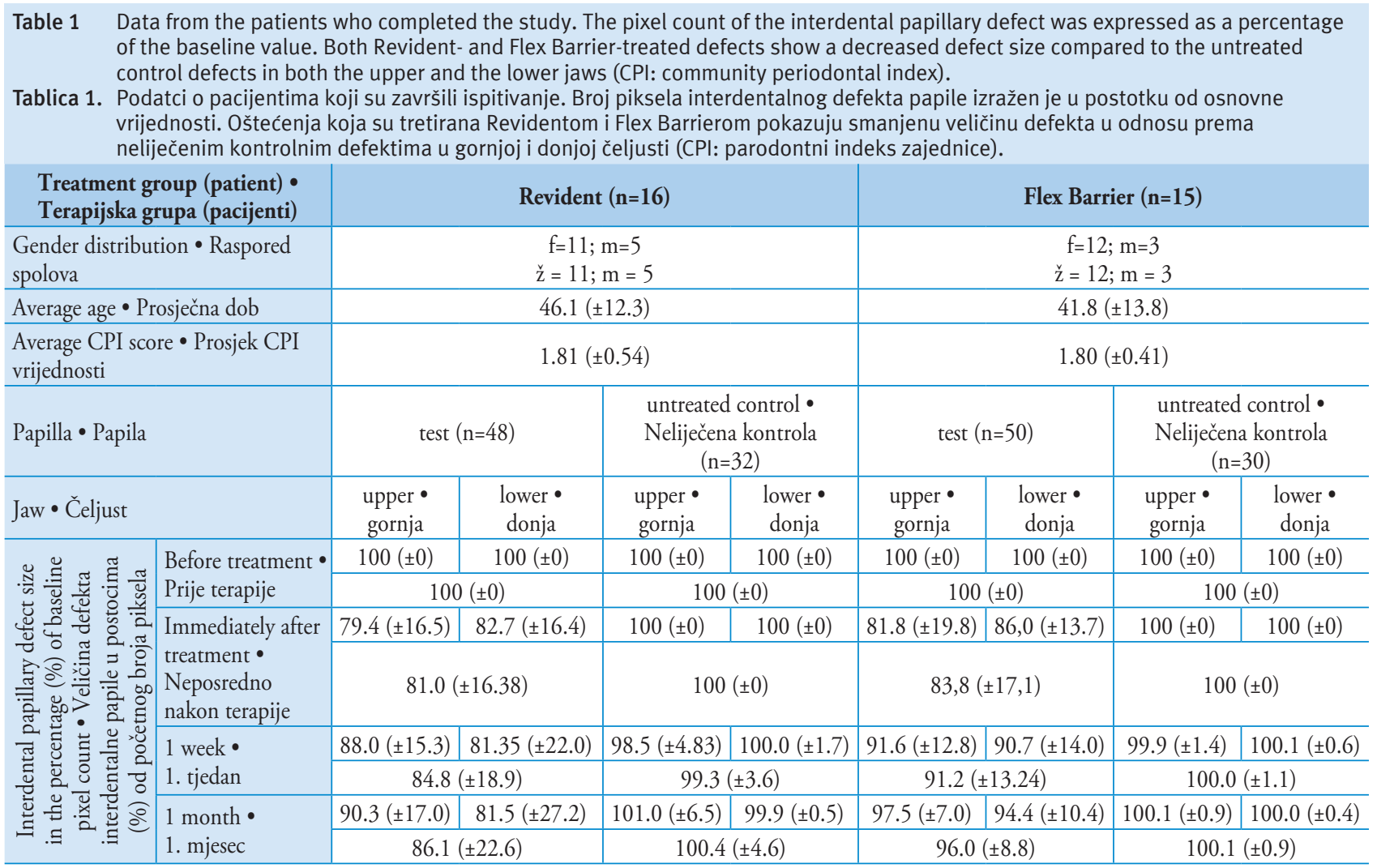



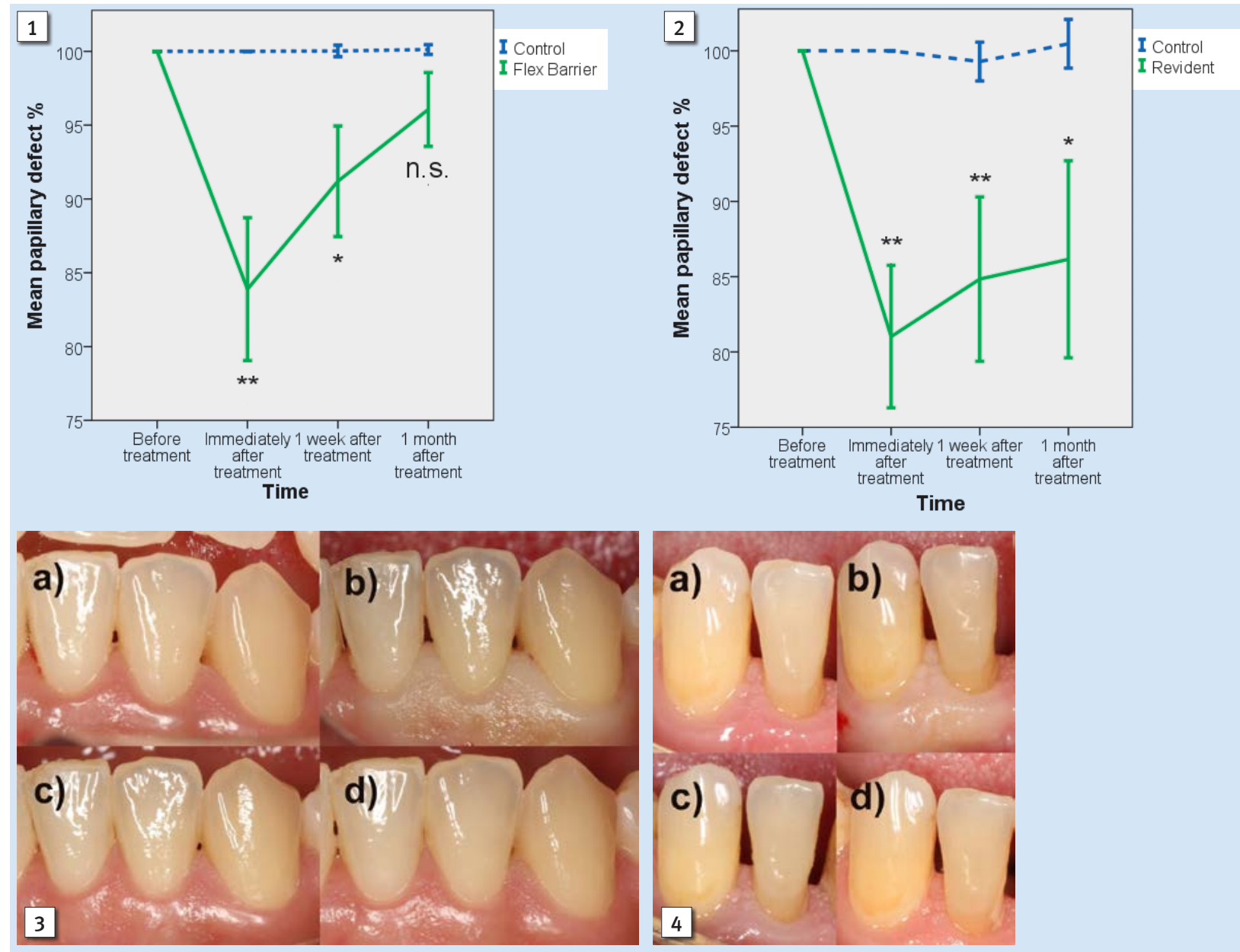

Figure 1 Changes in the mean papillary defect size in the Flex Barrier group: the treated defects (the green line) showed a significant decrease compared to the control baseline. The initially beneficial effect had diminished after one week and at the one-month follow-up. However, the mean defect size did not return to the initial size measured at baseline. The mean size of the untreated (control) papillary defects in the same patients (the blue dashed line) did not reveal any change throughout the follow-up period. The error bars represent the standard error of the mean for both the treated and the untreated defects. ${ }^{\star} p<0.05 ;{ }^{\star \star} p<0.01$ versus control.

Slika 1. Promjene prosječne veličine papilarnog defekta u skupini Flex Barrier: tretirani defekti (zelena linija) značajno su smanjeni u usporedbi s kontrolnom osnovom. Na početku se blagotvorni učinak smanjio nakon tjedan dana i nakon jednomjesečnog praćenja. No srednja veličina oštećenja nije se vratila na početnu veličinu izmjerenu prije terapije. Srednja veličina neliječenih (kontrolnih) papilarnih defekata kod istih pacijenata (plava isprekidana linija) nije pokazala promjene tijekom razdoblja praćenja. Trake pogrešaka predstavljaju standardnu pogrešku srednje vrijednosti i za tretirane i za neobrađene nedostatke. ${ }^{*} P<0,05 ;{ }^{\star \star} p<0,01$ u odnosu prema kontroli.

Figure 2 Changes in the mean papillary defect size in the Revident group: the treated defects (the green line) showed a significant decrease compared to the control baseline. The slight relapses in the beneficial effects could be seen after one week and at the one-month follow-up, however the mean defect size did not return to the initial size measured at the baseline. The mean size of the untreated (control) papillary defects in the same patients (the blue dashed line) did not show any change throughout the follow-up period. The error bars represent the standard error of the mean for both the treated and the untreated defects. ${ }^{*} \mathrm{p}<0.05 ;{ }^{* \star} \mathrm{p}<0.01$ versus control.

Slika 2. Promjene srednje veličine papilarnog defekta u skupini Revident: tretirani defekti (zelena linija) značajno su smanjeni u usporedbi s kontrolnom osnovom. Neka ponavljanja korisnih učinaka mogla su se uočiti nakon tjedan dana i nakon jednomjesečnog praćenja, no prosječna veličina defekta nije se vratila na početnu veličinu izmjerenu prije terapije. Srednja veličina neliječenih (kontrolnih) papilarnih defekata kod istih bolesnika (plava isprekidana linija) nije pokazala promjene tijekom razdoblja praćenja. Trake pogrešaka predstavljaju standardnu pogrešku srednje vrijednosti i za liječene i za neliječene defekte. ${ }^{\star} \mathrm{P}<0,05 ;{ }^{\star \star} \mathrm{p}<0,01 \mathrm{u}$ odnosu prema kontroli.

Figure 3. Changes in the appearance of a small (Nordland-Tarnow Class I) papillary defect after the Revident treatment (patient 5). (a) "Black triangles" at the baseline; (b) immediately after the injection: the paleness of the papillae and the attached gingiva is due to the injected gel; (c) at the one-week check-up: both defects were noticeably decreased; (d) at the one-month follow-up, suggesting further improvement. Complete resolution of small papillary defects is achievable with a single administration of Revident gel in this case.

Slika 3. Promjene u izgledu malog (papilarnog) oštećenja (Nordland-Tarnowa klasa I) nakon liječenja Revidentom (pacijent 5). (a) Crni trokut na početku; (b) odmah nakon injekcije: bljedoća papile i priložene gingive nastaje zbog ubrizgavanja gela; (c) tijekom jednotjednog pregleda: oba oštećenja vidljivo su manja; (d) nakon jednomjesečnog praćenja uočava se dodatno poboljšanje. Potpuno rješavanje malih papilarnih oštećenja može se u ovom slučaju postići jednim ubrizgavanjem gela Revident.

Figure 4 Changes in the appearance of a large (Nordland-Tarnow Class II) papillary defect after the Revident treatment (patient 13). (a) "Black triangles" at the baseline; (b) immediately after the injection; (c) at the one-week follow-up; (d) at the one-month follow-up. Large defects do not show clinically noticeable changes after a single administration of hyaluronic acid gel.

Slika 4. Promjene u izgledu velikoga papilarnog oštećenja (Nordland-Tarnowa klasa II) nakon liječenja Revidentom (pacijent 13). (a) Crni trokut na početku; (b) odmah nakon injekcije; (c) praćenje nakon tjedan dana; (d) kontrola nakon mjesec dana. Veliki defekti ne pokazuju klinički primjetne promjene nakon jednokratne primjene gela s hijaluronskom kiselinom. 
The other treatment group received Revident, a gift from its manufacturer, CLS LLC (Moscow, Russia). Revident is a $1 \%$ hyaluronic acid formulation for clinical use. The hyaluronic acid substrate in this gel was the same as in Flex Barrier. During its preparation, hyaluronic acid is modified by adding a water-soluble extract of wheat-germ root, principally a neutral hydrophilic complex of polysaccharides. Both of these ingredients are readily soluble in water $(17,18)$. The components of wheat-germ extract have been shown to exhibit antiinflammatory effects $(19,20)$, to stimulate osteogenic differentiation, to increase cell adhesion capability $(22,23)$ and also to enhance cell proliferation $(23,24)$. Such mixtures have already been used in vivo for targeted delivery to liver cells (25).

After the first examination, the patients were randomly allocated to one of the test groups by coin tossing. In the Flex Barrier group (Flex Barrier; $n=20$ ) at least one upper and one lower papilla was treated with Flex Barrier gel following the "Three Step Technique" (TST), as recommended by the manufacturer, while at least one upper and one lower papillary defect was left untreated and served as a negative control. The TST method consisted of the following steps: (1) injection of the gel with a $30 \mathrm{G}$ needle along the mucogingival junction at the base of the papilla at 4-5 sites, creating depots of $0.1 \mathrm{ml}$ per site, (2) injection of the gel into the attached gingiva at the base of the papilla at 2-3 sites, creating depots of $0.1 \mathrm{ml}$ per site, (3) injection of the gel into the papilla $2-3 \mathrm{~mm}$ from its tip at one site, creating a depot of 0.1 $\mathrm{ml}$. In the Revident group (Revident; $\mathrm{n}=20$ ) the same treatment was performed using the Revident gel. Again, at least one upper and one lower untreated papilla served as negative controls. All the treatments were performed by the same clinician in the same clinical setting.

Photographic documentation of treated papillae was performed immediately after the injection of hyaluronic acid gel, applying exactly the same settings as before treatment. The follow-up assessments of the volumetric changes in the treated and control papillae were carried out one week and one month after the treatment and consisted of photo documentation and a visual reassessment according to the Nordland-Tarnow classification. A retreatment of previously treated papillae and the treatment of untreated negative control papillae was performed upon patient's request after the one month follow-up.

The analysis of digital photographs was performed using ImageJ software (26). All measurements were performed by the same investigator. First, a standard distance (the mesiodistal width of a tooth neighboring the papillary defect) was measured on each photograph to set the scale. Using this scale setting, outlines of the interdental "black triangle" indicating the papillary defect were drawn with the help of the Image J polygon tool. The area of the polygon was automatically calculated by the software. Changes in the "black triangle" area were expressed as a percentage of the initial lesion area. Decreases in lesion size indicated increases in papilla size.

A mixed-design ANOVA analysis (IBM SPSS Statistics 19) was used with the Bonferroni post-hoc tests to evaluate the differences between the hyaluronic acid-treated and the control papillae (the between-subjects factor) and between the time points (within-subjects factor).
Druga skupina dobila je za liječenje Revident, dar proizvođača CLS LLC (Moskva, Rusija). Revident je 1-postotna formulacija hijaluronske kiseline za kliničku upotrebu. Supstrat hijaluronske kiseline u ovom gelu bio je isti kao u Flex Barrieru. Tijekom njegove pripreme hijaluronska kiselina se modificira dodavanjem ekstrakta korijena pšeničnih klica topivog u vodi, uglavnom neutralnog hidrofilnog kompleksa polisaharida. Oba sastojka lako su topiva u vodi $(17,18)$. Pokazalo se da komponente ekstrakta pšeničnih klica djeluju protuupalno $(19,20)$, potiču osteogenu diferencijaciju (21), povećavaju svojstvo adhezije stanica $(22,23)$ i povećavaju njihovu proliferaciju $(23,24))$. Takve smjese već su korištene in vivo za ciljanu dostavu u jetrene stanice (25).

Nakon prvog pregleda pacijenti su nasumično raspoređeni u jednu od testnih skupina bacanjem novčića. U grupi Flex Barrier (Flex Barrier; $\mathrm{n}=20$ ) najmanje jedna gornja i jedna donja papila injicirane su gelom Flex Barrier tehnikomi u tri koraka (TST) prema preporuci proizvođača, a barem su jedna gornja i jedna donja papila s defektom ostavljene neliječene i služile su kao negativna kontrola. TST metoda sastojala se od sljedećega: (1) ubrizgavanja gela iglom promjera 30 duž mukogingivnog spoja u podnožju papile na 4 do mjesta, stvarajući depo od 0,1 mL po mjestu; (2) ubrizgavanja gela u pričvrsnu gingivu na dnu papile na 2 do 3 mjesta, stvarajući depo od $0,1 \mathrm{~mL}$ po mjestu; (3) ubrizgavanja gela u papilu 2 do $3 \mathrm{~mm}$ od vrha na jednom mjestu, stvarajući depo od $0,1 \mathrm{~mL}$. U grupi Revident (Revident; $\mathrm{n}=20$ ) jednaki tretman obavljen je primjenom gela Revident. Ponovno su, barem jedna gornja i jedna donja neliječena papila, služile kao negativna kontrola. Sve terapijske zahvate obavljao je isti kliničar u istom kliničkom okružju.

Fotografska dokumentacija liječenih papila učinjena je odmah nakon injekcije gela hijaluronske kiseline, primjenjujući točno iste postavke kao i prije liječenja. Kontrolne procjene volumetrijskih promjena na liječenim i kontrolnim papilama obavljene su tjedan dana i mjesec dana poslije tretmana, a sastojale su se od fotodokumentacije i ponovne vizualne procjene prema klasifikaciji Nordland-Tarnowa. Ponovno tretiranje liječenih papila i liječenje neobrađenih negativnih kontrolnih papila provelo se na zahtjev pacijenta nakon jednomjesečnog kontrolnog praćenja.

Analiza digitalnih fotografija učinjena je softverom Image J (26). Sva mjerenja obavio je isti istraživač. Najprije se mjerila standardna udaljenost (meziodistalna širina zuba koji je susjedni papilarnom defektu) kako bi se postavilo mjerilo. $S$ pomoću te postavke mjerila, alatom za poligon Image J nacrtani su obrisi interdentalnog crnog trokuta koji označuju papilarni defekt. Softver automatski izračunava površinu poligona. Promjene u području crnog trokuta izražene su u postotku od početnoga područja lezije. Smanjenje lezije upućuje na povećanje papile.

Korištena je miješana ANOVA analiza (IBM SPSS Statistics 19) s Bonferronijevim post-hoc testovima za procjenu razlika između papila liječenih hijaluronskom kiselinom i kontrolnih papila (čimbenik između subjekata) i različitih vremenskih točaka (čimbenik unutar subjekta). 


\section{Results}

Nine of the 40 patients included in the study were excluded from the analysis. Eight of them did not attend the control appointments, while one patient had herpetic lesions of the attached gingiva around the treated area developed by the time of the one-week recall appointment. Therefore, the exact measurements of the papillae dimensions could not have been performed for that individual. Data from 31 patients and a total of 160 papillae were analyzed (Revident test: $n=$ 48, Revident control: $\mathrm{n}=32$, Flex Barrier test: $\mathrm{n}=50$, Flex Barrier control: $\mathrm{n}=30$ ). Altogether 98 papillae were treated with one of the two hyaluronic acid gels, while 62 were used as control sites. The average age of the 31 patients who completed the study was $44.0( \pm 13.03$; Revident group: 46.1 \pm 12.3 , Flex Barrier group: $41.8 \pm 13.8) .23$ of them were females (Revident group: 11, Flex Barrier group: 12) and eight of them were males (Revident group: 5, Flex Barrier group: 3)

In the Flex Barrier group, the results of the mixed-design ANOVA showed that interdental papillary defect size was significantly affected by the administration of the gel (betweensubjects factor): $\mathrm{F}(1,78)=23.27, \mathrm{p}<0.001$ with a large effect size $\left(\eta^{2}=0.230\right)$. There was also a significant interaction between time and Flex Barrier administration F(1.96, 152.63) $=15.45, p<0.001$. Since the Mauchly's test of sphericity was violated, a Greenhouse-Geisser test was used. The partial $\eta^{2}$ effect size $\left(\eta^{2}=0.165\right)$ indicated that the effect of the interaction was moderate. A Bonferroni post-hoc test revealed that the defect size decreased significantly right after the administration of the gel $(p<0.001)$. The treated defect areas then increased significantly $(p=0.43)$ over the first week of follow-up but remained significantly smaller $(p<0.01)$ than the control defects. There was also a significant increase $(p<0.01)$ in the defective area between one week and one month at the treated sites, and there was no significant difference $(p=0.127)$ between the test and the control sites at the end of the investigation (Figure 1).

In the Revident group, the results of the mixed-design ANOVA showed that interdental papillary defect size was significantly affected by the administration of the gel (betweensubjects factor): $F(1,78)=26.26, p<0.001$ with a large effect size $\left(\eta^{2}=0.252\right)$. There was also a significant interaction between time and Revident administration F(1.91, 148.79) $=13.84, p<0.001$. Since the Mauchly's test of sphericity was violated, a Greenhouse-Geisser test was used. The partial $\eta^{2}$ effect size $\left(\eta^{2}=0.151\right)$ indicated that the effect of the interaction was moderate. A Bonferroni post-hoc test revealed that defect size decreased significantly right after the administration of the gel $(p<0.001)$. The improvement showed a slight, but statistically not significant, decrease by the one week ( $\mathrm{p}=$ $1.000)$ and the one month ( $p=0.697)$ follow-ups. At the end of the investigation, the treated defect areas remained significantly smaller $(\mathrm{p}<0.01)$ than the untreated control defects (Figure 2).

The comparison of the two treatment groups demonstrated that there was no significant difference between the control defects $(F(1,60)=0.075, p=0.786)$, while the type of gel

\section{Rezultati}

Devet od 40 bolesnika uključenih na početku u studiju isključeno je iz analize. Osam njih nije dolazilo na kontrolne preglede, a jednom su se pacijentu prije jednotjedne kontrole pojavile herpetičke lezije na gingivi oko tretiranog područja. Zbog toga mu se nisu mogla obaviti točna mjerenja dimenzija papile. Analizirani su podatci od 31 pacijenta i ukupno 160 papila (revidentni test: $n=48$, revidentna kontrola: $n=32$, test fleksibilne barijere: $n=50$, kontrola fleksibilne barijere: $\mathrm{n}=30$ ). Ukupno 98 papila tretirano je jednim od dvaju gelova s hijaluronskom kiselinom, a 62 papile korištene su kao kontrolna mjesta. Prosječna dob 31 pacijenta koji su završili ispitivanje bila je 44,0 godina $( \pm 13,03)$ (revidentna skupina: 46,1 $\pm 12,3$, skupina Flex Barrier: 41,8 \pm 13,8). 23 od njih bile su žene (skupina Revident: 11, skupina Flex Barrier: 12), a 8 muškarci (skupina Revident: 5, skupina Flex Barrier: 3)

U skupini Flex Barrier su rezultati mješovite ANOVA analize pokazali da je na interdentalni papilarni defekt značajno utjecala primjena gela (čimbenik između ispitanika): $\mathrm{F}(1,78)=23,27, \mathrm{p}<0,001$ i velika veličina efekta $(\eta 2=$ $0,230)$. Također se dogodila značajna interakcija između vremena i primjene preparata Flex barrier F $(1,96,152,63)=$ $15,45, p<0,001$. Budući da je Mauchleyev test sferičnosti kršen, uporabljen je Greenhouse-Gessierov test. Djelomična veličina učinka $\eta 2(\eta 2=0,165)$ upućivala je na to da je učinak interakcije bio umjeren. Bonferronijev post-hoc test pokazao je da se veličina defekta značajno smanjila odmah nakon primjene gela $(\mathrm{p}<0,001)$. Obrađena područja oštećenja tada su se značajno povećala $(\mathrm{p}=0,43)$ tijekom prvog tjedna praćenja, ali su ostala značajno manja ( $<<0,01)$ u odnosu prema kontrolnim nedostatcima. Zabilježeno je i značajno povećanje $(\mathrm{p}<0,01)$ na području oštećenja između jednog tjedna i jednog mjeseca na obrađenim mjestima, a na kraju ispitivanja nije bilo značajne razlike $(\mathrm{p}=0,127)$ između ispitnih i kontrolnih mjesta (slika 1.).

U skupini Revident, rezultati mješovite ANOVA analize pokazali su da je na interdentalni papilarni defekt značajno utjecala primjena gela (čimbenik između ispitanika): $\mathrm{F}$ $(1,78)=26,26, p<0,001 s$ velikom veličinom učinka $(\eta 2$ $=0,252)$. Također se dogodila značajna interakcija između vremena i primjene Revidentna $\mathrm{F}(1,91,148,79)=13,84$, p $<.001$. Budući da je Mauchleyev test sferičnosti kršen, uporabljen je Greenhouse-Gessierov test. Djelomična veličina učinka $\eta 2(\eta 2=0,151)$ upućivala je na to da je učinak interakcije bio umjeren. Bonferronijev post-hoc test pokazao je da se veličina defekta značajno smanjila odmah nakon primjene gela $(\mathrm{p}<0,001)$. Poboljšanje je pokazalo neznatno, ali statistički ne značajno, smanjenje nakon jednog tjedna ( $\mathrm{p}=$ $1,000)$ i jednog mjeseca $(\mathrm{p}=0,697)$. Na kraju ispitivanja tretirana crna područja ostala su značajno manja $(\mathrm{p}<0,01)$ od neobrađenih kontrolnih područja (slika 2.).

Usporedba dviju liječenih skupina pokazala je da nije bilo značajne razlike između kontrolnih oštećenja $(\mathrm{F}(1,60)=$ $0,075, p=0,786)$, a vrsta korištenog gela znatno utječe na smanjenje veličine defekta $(\mathrm{F}(1,96)=0,032, \mathrm{p}=0,032)$, gdje se pokazalo da je Revident učinkovitiji. No, djelomična 
used had a significant effect on the decrease in the defect size $(F(1,96)=0,032, p=0.032)$, where Revident proved more effective. However, the partial $\eta^{2}$ effect size $\left(\eta^{2}=0.047\right)$ indicated that the effect of the gel type on defect size was small.

We performed these evaluations in both the NordlandTarnow Class I type and II type patients (Figures 3-4). Most of the papillae included in the study were the Nordland-Tarnow Class II type. Our results show that in this type of papillary lesion neither of the investigated hyaluronic acid gels caused improvements that were noticeable to the patients, although we could measure improvements by image analysis (Figure 4). Class I lesions exposed a greater improvement that was noticeable for the patients by subjective judgement (Figure 3). As a general rule, we can state that the smaller the initial lesion, the greater the improvement in the reduction of the "black triangle" lesion. However, the long-term results are largely dependent on the patient's individual interdental oral hygiene rather than on the type of hyaluronic acid gel. In the cases where plaque accumulation was observed during the recall visits, no improvement has been detected compared to the baseline lesion, irrespective of the type of the gel used.

We also investigated many other papillae, both in the upper and lower jaws, to exclude possible biasing effects of the choice of the site for treatment. Our results show that both the upper and lower sites responded similarly.

In the preliminary screening for possible long-term effects of treatment, four patients in the Revident group had been regularly checked for up to 18 months after the initial application of the hyaluronic acid gel. No harmful long-term effects were observed.

\section{Discussion}

As Bertl et al. stated in their systematic review, having investigated the adjunctive effects of hyaluronan on periodontal therapy, recommendations for clinical application should be based on repeated positive outcomes in multiple controlled clinical trials (27). Therefore, there has been a strong need for robust scientific data to evaluate the use of hyaluronan injections for interdental papillary augmentation. By using two different, injectable hyaluronic acid-containing gel preparations, Flex Barrier and Revident, we have shown that even a single administration of these gels effectively decreases the size of "black triangles" in patients with Nordland-Tarnow Class I and II type recessions.

Advantageous physicochemical properties of hyaluronic acid include biodegradability, non-toxicity, biocompatibility, and non-immunogenicity. These properties make them suitable for various biomedical applications (28), such as intra-articular (osteoarthritis) (29), cosmetic (dermal implantation and wrinkle correction) (30), and topical uses (wound dressing and treatment of burns) $(31,32)$. Hyaluronan production increases in proliferating cells, and the polymer may play a role in mitosis (33). Recent investigations have found that cross-linked hyaluronic acid hydrogel is also an excellent biodegradable scaffold for tissue engineering and regenerative medicine $(34,35)$. veličina efekta $\eta 2(\eta 2=0,047)$ upućivala je na to da je učinak vrste gela na veličinu oštećenja bio mali.

Obavili smo ove procjene i za bolesnike I. i II. razreda Nordland-Tarnowe klasifikacije (slike 3. i 4.). Većina papila uključenih u studiju bile su II. klase Nordland-Tarnowa. Naši rezultati pokazuju da u toj vrsti papilarne lezije nijedan od ispitivanih gelova $s$ hijaluronskom kiselinom nije potaknuo poboljšanja koja su bila vidljiva pacijentima, iako smo poboljšanja mogli izmjeriti analizom slike (slika 4.). Lezije klase I pokazale su veće poboljšanje koje je bilo vidljivo kod pacijenata prema subjektivnom prosuđivanju (slika 3.). Kao opće pravilo možemo istaknuti da što je manja početna lezija, to je veće smanjenje lezije crnog trokuta. No dugoročni rezultati u velikoj mjeri ovise o pacijentovoj interdentalnoj oralnoj higijeni, a ne o vrsti gela s hijaluronskom kiselinom. U slučaju kada je došlo do nakupljanja plaka tijekom opoziva, nije se moglo opaziti poboljšanje u usporedbi s osnovnom lezijom, bez obzira na uporabljeni gel.

Istražili smo također velik broj drugih papila u gornjoj i donjoj čeljusti kako bismo isključili moguće pristrane učinke izbora mjesta za liječenje. Naši rezultati pokazuju da su gornja i donja mjesta reagirala slično.

U preliminarnom pregledu mogućih dugoročnih učinaka liječenja, četiri su pacijenta iz skupine Revident redovito pregledavana do 18. mjeseca nakon početne primjene gela s hijaluronskom kiselinom. Nisu uočeni dugoročni štetni učinci.

\section{Rasprava}

Kao što Bertl i suradnici navode u svojem sustavnom pregledu, istražujući adekvatne učinke hijalurona na parodontnu terapiju, preporuke za kliničku primjenu trebaju se temeljiti na ponovljenim pozitivnim ishodima u višekratnim kontroliranim kliničkim ispitivanjima (27). Zato je postojala velika potreba za snažnim znanstvenim podatcima kako bi se procijenila primjena hijaluronskih injekcija za interdentalno povećanje papila. Upotrebom dvaju različitih gelova koji sadržavaju injekcijsku hijaluronsku kiselinu - Flex Barriera i Revidenta, pokazali smo da čak i jednokratna primjena tih gelova učinkovito smanjuje veličinu crnib trokuta kod pacijenata s recesijom Nordland-Tarnowove klase I i II.

Pogodna fizikalno-kemijska svojstva hijaluronske kiseline uključuju biorazgradivost, netoksičnost, biokompatibilnost i neimunogenost. To ih čini pogodnima za razne biomedicinske primjene (28), kao što su intraartikularna (osteoartritis) (29), kozmetička (implantacija pod kožu i uklanjanje bora) (30) i za lokalnu upotrebu (previjanje rana i liječenje opeklina) $(31,32)$. Proizvodnja hijalurona povećava se u stanicama koje se umnažaju, a polimer može biti važan u mitozi (33). U nedavnim istraživanjima autori su otkrili da je umreženi hidrogel s hijaluronskom kiselinom također izvrsna biorazgradiva podloga za tkivno inženjerstvo i regenerativnu medicinu $(34,35)$. 
A new systematic review clearly identifies the main application areas of hyaluronic acid in dentistry (36), such as adjuvant treatment of gingivitis and periodontitis (36-39), and in various surgical procedures including dental implantation, sinus lift and impacted third molar surgeries (40), as well as the treatment of aphthous ulcers (41). Although the data show some beneficial results in the treatment of temporomandibular joint disorders (42), the FDA approved this therapy only for the use in knee osteoarthritis (43).

Our study is the first randomized clinical trial demonstrating that clinically applicable hyaluronic acid preparations are effective, with single administration, in the treatment of gingival "black triangles" in humans. Furthermore, our data indicate that although both preparations are effective, Revident gave longer-lasting effects than Flex Barrier.

Since the technique for papillary augmentation by hyaluronan fillers was first introduced by Becker and co-workers (10), several single- or multiple-case, noncontrolled followup studies have been conducted to investigate the effectiveness of hyaluronic acid injections. Becker et al. treated 14 sites in 11 patients. Sites adjacent to teeth (6) and implants (12) were both included. The number of treatment sessions ranged between one and three, depending on the results seen at control visits, but, unfortunately, no control sites were investigated. The follow-up period ranged from six to 25 months and success ranged between 57 and 100\% (10).

Mansouri et al. investigated 21 interdental papillae in 11 patients treated with hyaluronic acid gel injections, again without the assessment of the control sites. Injections were repeated up to three times on control visits, based on an individual assessment, and all patients were followed-up for six months. A mean success rate of $47.3 \pm 20.2 \%$ (range 22 $100 \%)$ in papilla reconstruction was reported (11).

Lee and co-investigators treated 43 maxillary anterior papillary defects in 10 patients, also without the investigation of control sites. Administration of the gel was repeated up to five times (mean 3.4), based on individual assessment, at three-week intervals, and patients were followed up for six months. Complete reconstruction rates were recorded at 29 sites (100\%) and partial reconstruction rates (39-96\%) at 14 sites, with a mean of $92.5 \%$ (13). They also reported another study involving 57 upper anterior sites in 13 patients, with no control group, where administration of the gel was repeated up to five times (mean 3.33) at three-week intervals. That study reported an $88.8 \%$ mean papillary reconstruction rate after six months.

Awartani and co-workers treated 17 sites (13 maxillary, four mandibular) in nine patients with no control group. The hyaluronic-acid-containing gel was administered three times, with repeats at 21 and 42 days after the initial session, and patients were followed up for six months. Papillary defects showed a $0-100 \%$ reduction at six months with a mean of $41 \pm 37 \%$ (12).

Finally, a recent study by Bertl et al. investigated $21 \mathrm{pa}-$ tients with papillary deficiencies between implants and natural teeth. 11 papillae were treated with hyaluronic acid gel while 10 more were treated with physiological saline solution as a control. The injections were repeated four weeks after the
Nedavni sustavni pregledni radovi jasno su identificirali glavna područja primjene hijaluronske kiseline u stomatologiji (36), poput potpornog liječenja gingivitisa i parodontitisa $(36$ - 39) te u raznim kirurškim zahvatima, uključujući postavljanje zubnih implantata, podizanje dna sinusa i operacije trećih kutnjaka ( 40) te liječenje aftoznih ulkusa (41). Iako podatci pokazuju neke povoljne rezultate u liječenju poremećaja temporomandibularnog zgloba (42), FDA je odobrila tu terapiju samo u slučaju osteoartritisa koljena (43).

Naše istraživanje prvo je randomizirano kliničko ispitivanje koje pokazuje da je klinička primjena hijaluronske kiseline učinkovita, i samo u slučaju jednokratne primjene, u liječenju gingivnih crnih trokuta kod ljudi. Nadalje, naši podatci govore da, iako su oba pripravka učinkovita, Revident postiže dugotrajnije rezultate u odnosu prema Flex Barrieru.

Naše je istraživanje prvo randomizirano kliničko ispitivanje koje pokazuje da su klinički primjenjivi pripravci hijaluronske kiseline učinkoviti, s jednom primjenom, u liječenju gingivalnih „crnih trokuta” kod ljudi. Nadalje, naši podaci govore da iako su oba pripravka učinkovita, Revident daje dugotrajnije efekte u odnosu na Flex Barrier.

Budući da su tehniku povećanja papila hijaluronskim punilima prvi uveli Becker i suradnici (10), primijenjena je u nekoliko pojedinačnih slučaja ili više slučajeva nekontroliranih praćenja kako bi se istražila učinkovitost injekcija hijaluronske kiseline. Prema Beckeru i suradnicima, liječeno je 14 mjesta kod 11 pacijenata. Uključena su bila područja koja se nalaze uz liječene zube (6) i uz implantate (12). Broj posjeta tijekom liječenja kretao se između jednog i tri, ovisno o rezultatima na kontrolama, ali nažalost nisu ispitana kontrolna mjesta. Razdoblje praćenja bilo je u rasponu od 6 do 25 mjeseci, a uspjeh između 57 i $100 \%$ (10).

Mansouri i suradnici ispitali su 21 interdentalnu papilu kod 11 pacijenata liječenih injekcijama gela hijaluronske kiseline, ponovno bez procjene kontrolnih mjesta. Injekcije su ponovno dane tri puta tijekom kontrolnih posjeta na temelju individualne procjene, a svi su pacijenti praćeni šest mjeseci. U rekonstrukciji papila zabilježena je srednja stopa uspjeha od $47,3 \pm 20,2 \%$ (raspon $22-100 \%$ ) (11).

Lee i suradnici liječili su 43 oštećenja maksilarne prednje papile kod 10 pacijenata, također bez ispitivanja kontrolnih mjesta. Ubrizgavanje gela ponavljalo se do pet puta (prosječno 3,4$)$ na temelju individualne procjene, u razmacima od tri tjedna, a pacijente su pratili šest mjeseci. Dvadeset i devet papila potpuno se obnovilo obnove (100\%), a 14 djelomično $(39-96 \%)$, sa srednjom stopom od $92,5 \%$ (13). Također su izvijestili o drugoj studiji u kojoj je bilo obuhvaćeno 57 gornjih prednjih mjesta kod 13 pacijenata, bez kontrolne skupine, gdje se primjena gela ponavljala do pet puta (prosjek $3,33)$ u intervalima od tri tjedna. U toj je studiji istaknuto da je prosječna stopa obnavljanja papile iznosila $88,8 \%$ nakon šest mjeseci (14).

Awartani i suradnici liječili su 17 mjesta (13 maksilarnih, 4 mandibularna) kod 9 pacijenata, bez kontrolne skupine. Gel koji sadržava hijaluronsku kiselinu primijenjen je tri puta, s ponavljanjima 21. i 42. dana nakon početne sesije, a pacijenti su praćeni šest mjeseci. Papilarni defekti smanjili su se od 0 do $100 \%$ u 6 mjeseci, s prosjekom od $41 \pm 37 \%$ (12). 
initial treatment, and the patients were followed up for a period of six months. This study did not discover any significant reduction in the papillary defects, and no significant differences were observed between the test and the control values (44).

There is a large degree of variability in these studies: in the number of sites and patients involved, and in the number of hyaluronic acid gel administrations. Except for Bertl et al. (44), none of the research settings included control sites, but the Bertl et al. study only investigated papillae adjacent to implants. It is therefore hard to draw any firm conclusions from these reports, but it is clear that hyaluronic acid gel injection could have some beneficial effects since the mean success rate ranged from $0 \%$ to $93 \%$.

The two major reasons for the huge variation in the effectiveness of the treatment may be inconsistencies in gel administration and different intervals between retreatment visits. Therefore, in the present work one of our major aims was to investigate the effect of a single administration. Our data present that a single administration of the hyaluronic acid gel is effective when measuring "black triangles" in a standardized and reproducible way. But we should also admit that the outcome of the present work, in terms of the magnitude of changes, is inferior compared to some other studies in which multiple administration was performed (10-14). In our study, the effect also seemed to last for a very short time and shrinking of the augmented papillae was observed even in the short follow-up period.

The main inclusion criterion for the present study was the subjective esthetic complaint of the patients that they had "black triangles" between their teeth. We therefore included both the Nordland-Tarnow class I and class II patients in our work. Considering that the larger the lesion, the more disturbing it is for the patient, most of the cases were Nordland-Tarnow Class II types. Our present proof-of-concept study clearly demonstrates the effectiveness of both Revident and Flex Barrier gels on the periodontal defect. Additionally, it also shows that the single injection application of these compounds results in only a moderately positive clinical outcome. The results of the digital image analysis showed significant superiority of the Revident gel over the Flex Barrier gel. But we must also note that, using the single injection protocol, the difference between the two materials was not detectable by physical examination or a subjective visual evaluation by the patients. The reasons for this are discussed above. Large, disturbing Nordland-Tarnow class II "black triangle" defects decreased in size but did not disappear. Therefore, in clinical practice it seems to be reasonable to inform patients in advance about the possible necessity of multiple treatment sessions for better results. An exact recommendation on the number of retreatments has to be determined by well-designed randomized clinical studies in the future. Although the average age of the patients in the two treatment groups was comparable, it has to be noted that the relatively wide age range may have had an effect on the results as well, because the healing capacity and collagen density of gingival tissues change greatly with age. In the present study, the youngest patient treated was 20 , while the oldest was 66 years old. Future studies need to focus on a narrower age range to exclude this potentially confounding factor.
Konačno, u nedavnoj su studiji Bertl i suradnici istraživali 21 pacijenta s papilarnim defektom između implantata i prirodnih zuba. Gelom hijaluronske kiseline tretirano je $11 \mathrm{pa}-$ pila, a još 10 fiziološkom otopinom kao kontrolom. Injekcije su ponovljene 4 tjedna nakon početnog liječenja, a pacijenti su praćeni šest mjeseci. U tom istraživanju nije postignuto značajnije smanjenje papilarnih oštećenja i nisu uočene značajne razlike između testnih i kontrolnih vrijednosti (44).

Zabilježen je velik stupanj varijabilnosti u navedenim istraživanjima - u broju mjesta i pacijenata koji su bili uključeni te u broju gelova s hijaluronskom kiselinom. Osim studije Bertla i suradnika, (44), nijedno istraživanje nije uključivalo kontrolna mjesta, a i Bertl i suradnici proučavali su samo ispitivane papile pokraj implantata. Zato je teško izvući čvrste zaključke iz tih izvještaja, ali jasno je da bi ubrizgavanje gela s hijaluronskom kiselinom moglo koristiti jer je prosječna stopa uspjeha bila u rasponu od $0 \%$ do $93 \%$.

Dva glavna razloga za velike razlike u učinkovitosti liječenja mogu biti nedosljednost u primjeni gela i različiti intervali između posjeta liječniku. Zato je u ovom radu jedan od naših glavnih ciljeva bio istražiti učinak jednokratne primjene. Naši podatci pokazuju da je jednokratna primjena gela s hijaluronskom kiselinom doista učinkovita pri mjerenju crnih trokuta na standardiziran i ponovljiv način. No također bismo trebali priznati da je rezultat ovog rada, s obzirom na veličinu promjena, niži u odnosu prema nekim drugim studijama u kojima je provedeno višsestruko ubrizgavanje $(10-14)$. Čini se da je i u našem istraživanju učinak trajao vrlo kratko, a smanjivanje proširenih papila uočeno je i u kratkom razdoblju praćenja.

Glavni kriterij za uključivanje u ovo istraživanje bio je subjektivni estetski prigovor pacijenta da ima crne trokute između zuba. Zato smo u svoj rad uključili i pacijente I. i II. razreda Nordland-Tarnowa. S obzirom na to da su, što je veća lezija pacijenti uznemireniji, većina slučajeva bila je Nordland-Tarnowe klase II. Naša sadašnja studija dokaza o konceptu jasno pokazuje učinkovitost gela Revident i Flex Barrier na defektu parodonta. Uz to, također pokazuje da primjena tih spojeva pojedinačnom injekcijom rezultira samo umjereno pozitivnim kliničkim ishodom. Rezultati digitalne analize slike pokazali su značajnu superiornost gela Revident u usporedbi s Flex Barrierom. No također moramo napomenuti da se s pomoću protokola pojedinačnog ubrizgavanja razlika između dvaju materijala nije utvrdila fizičkim pregledom ili subjektivnom vizualnom procjenom pacijenata. Razlozi za to su već spomenuti. Veliki, uznemirujući nedostatci crnog trokuta Nordland-Tarnowe klase II smanjili su se u veličini, ali nisu nestali. Zato se čini da je u kliničkoj praksi razumno unaprijed obavijestiti pacijente o mogućim višestrukim posjetima radi postizanja boljih rezultata. Točna preporuka o broju potrebnih tretmana u budućnosti mora biti utvrđena dobro osmišljenim randomiziranim kliničkim studijama. Iako je prosječna dob pacijenata u našim dvjema skupinama bila usporediva, mora se napomenuti da je razmjerno velik dobni raspon mogao utjecati i na rezultate jer se ljekovito svojstvo i gustoća kolagena u tkivu gingive uvelike mijenjaju s dobi. $U$ našem istraživanju najmlađi pacijent imao je 20 godina, a najstariji 66. Buduće studije trebaju se usredotočiti na uže dobno razdoblje da bi se isključio taj potencijalno utjecajni čimbenik. 


\section{Conclusion}

In this proof-of-concept randomized clinical trial, the clinical applicability of two hyaluronic acid preparations, Flex Barrier and Revident has been demonstrated. In a single-injection protocol Revident showed longer lasting effects than Flex Barrier. Apart from showing effectiveness, this study clearly points out the need for further, well-designed randomized clinical trials in order to determine the optimal arrangements for treating gingival "black triangles" with multiple injections of hyaluronic acid.

\section{Acknowledgments}

This work was supported by the Human Resources Development Operational Programme Hungary (EFOP-3.6.2-16-2017-00006). Revident hyaluronic acid gel was provided by its manufacturer, CLS LLC (Moscow, Russia). The authors are grateful to Dr. Márk László Czumbel for his substantial technical help during the preparation of the manuscript and to Dr. Martin C. Steward for his valuable suggestions during the revision.

\section{Conflict of interest}

The authors declare no conflict of interest.

\section{Author contributions:}

I.M. - conceived and designed the experiments, contributed to data and analysis tools, performed the experiments, wrote the paper; S.F. - conceived and designed the experiments, contributed to data and analysis tools, contributed to writing the paper; G.V. - conceived and designed the experiments, contributed to writing the paper, supervised the result interpretation, corresponding author; Á.K.N. - conceived and designed the experiments, contributed to writing the paper, supervised the results, project administration. All the authors agreed on the publication.

\section{Zaključak}

U našem randomiziranom kliničkom ispitivanju $s$ dokaznim konceptom pokazali smo kliničku primjenu dvaju preparata s hijaluronskom kiselinom - Flex Barriera i Revidenta. U protokolu s jednom injekcijom Revident je postigao dugotrajnije efekte u odnosu prema Flex Barrieru. Osim što pokazuje učinkovitost, naš rad jasno upućuje na to da su potrebna daljnja dobro osmišljena randomizirana klinička ispitivanja kako bi se odredio optimalni način za liječenje gingivnih $\mathrm{cr}$ nih trokuta višestrukim injekcijama hijaluronske kiseline.

\section{Zahvale}

Ovaj rad je podupro Human Resources Development Operational Programme Hungary (EFOP-3.6.2-16-2017-00006). Hijaluronski gel Revident osigurao je proizvođač CLS LLC (Moskva, Rusija). Autori zahvaljuju dr. Márku Lászlu Czumbelu za njegovu veliku tehničku pomoć pri pripremi ovoga rada i dr. Martinu C. Stewardu za vrijedne prijedloge tijekom revidiranja.

\section{Sukob interesa}

Autori izjavljuju da nisu bili u sukobu interesa.

\section{Doprinosi autora}

I. M. - osmislio je i dizajnirao eksperimente, pridonio je prikupljanjem podataka i analitičkim alatima, obavljao je eksperimente, napisao je rad; S. F. - osmislio je i dizajnirao eksperimente, pridonio je prikupljanjem podataka i analitičkim alatima, pridonio je pisanju rada; G. V. - osmislio je i dizajnirao eksperimente, pridonio je pisanju rada, nadzirao je interpretaciju rezultata, autor je za korespondenciju; Á. K. N. - osmislio je i dizajnirao eksperimente, pridonio je pisanju rada, nadzirao je rezultate, administrativno je pratio projekt. Svi autori složili su se da se rad može objaviti.

\begin{abstract}
Sažetak
Ciljevi: Željela se istražiti učinkovitost pojedinačnih injekcija dvaju različitih proizvoda s hijaluronskom kiselinom - Flex Barriera i Revidenta, u smanjenju veličine crnih trokuta tijekom liječenja recesija poput NordlandTarnowe klase I i II. Materijali i metode: Četrdeset odraslih pacijenata odabrano je s najmanje dvama gornjim i dvama donjim interdentalnim oštećenjima papile u frontalnom području među očnjacima. Prema klasifikaciji Nordland-Tarnowovih papilarnih oštećenja u ispitivanje su bile uključene i recesije I. i II. razreda. Pacijenti su nasumično raspoređeni u eksperimentalne skupine kako bi primili pojedinačne injekcije dvaju različitih proizvoda s hijaluronskom kiselinom - bilo Flex Barrier, bilo Revident. Neobrađene stranice poslužile su kao kontrole. Fotografije su snimljene prije tretmana i odmah poslije njega, te ponovno nakon tjedan i mjesec dana. Za određivanje veličine crnih trokuta korišten je softver Image J. Za statističke analize primijenjen je miješani oblik ANOVA analize. Rezultati: Flex Barrier i Revident značajno su smanjili tretirane nedostatke odmah nakon tretmana, a također tjedan dana poslije $(p<0,001)$. Blagotvorni učinak Revidenta trajao je dulje od onoga Flex Bariera, jer je djelovao i nakon mjesec dana kod pacijenata liječenih Revidentom, ali ne u skupini liječenoj Flex Barrierom. Nadalje, lezije klase I Nordland-Tarnowa općenito su pokazale veće poboljšanje od lezija klase II. Zaključak: U ovom dokumentiranom konceptu randomiziranog kliničkog ispitivanja pokazali smo kliničku primjenjivost i Flex Barriera i Revidenta, iako su s Revidentom postignuta dugotrajnija poboljšanja u usporedbi s Flex Barrierom. Daljnja ispitivanja potrebna su zbog optimizacije protokola s višestrukim aplikacijama za liječenje gingivnih crnih trokuta.
\end{abstract}

Zaprimljen: 18. veljače 2020.

Prihvaćen: 28. lipnja 2020.

Adresa za dopisivanje

Gábor Varga

Sveučilište Semmelweis

Stomatološki fakultet

Zavod za oralnu biologiju

Budapest, Hungary

varga.gabor@dent.semmelweis-univ.hu

Ključne riječi

povlačenje gingive; interdentalna papila; hijaluronska kiselina

\section{References}

1. Prica Oreški N, Čelebić A, Petričević N. Assessment of Esthetic Characteristics of the Teeth and Surrounding Anatomical Structures. Acta stomatologica Croatica. 2017 Mar;51(1):22-32.
2. Gonzalez MK, Almeida AL, Greghi SL, Pegoraro LF, Mondelli J, Moreno T. Interdental papillary house: a new concept and guide for clinicians. Int J Periodontics Restorative Dent. Nov-Dec 2011;31(6):e87-93. 
3. Chen MC, Liao YF, Chan CP, Ku YC, Pan WL, Tu YK. Factors influencing the presence of interproximal dental papillae between maxillary anterior teeth. J Periodontol. 2010 Feb;81(2):318-24.

4. Chow YC, Eber RM, Tsao YP, Shotwell JL, Wang HL. Factors associated with the appearance of gingival papillae. J Clin Periodontol. 2010 Aug 1;37(8):719-27.

5. Souza CA, Mourão Pinho RC, Cavalcanti de Siqueira RA, Freitas Santos de Andrade AL, de Carvalho Farias Vajgel B, da Silva Neto JC, et al. Factors Influencing the Presence of Papilla between Adjacent Implants and between a Tooth and an Implant. 2019 Dec;53(4):337-346.

6. Sharma AA, Park JH. Esthetic considerations in interdental pa pilla: remediation and regeneration. J Esthet Restor Dent. 2010 Feb;22(1):18-28.

7. Prato GP, Rotundo R, Cortellini P, Tinti C, Azzi R. Interdental papilla management: a review and classification of the therapeutic approaches. Int J Periodontics Restorative Dent. 2004 Jun;24(3):246-55

8. Geurs NC, Romanos AH, Vassilopoulos PJ, Reddy MS. Efficacy of micronized acellular dermal graft for use in interproximal papillae regeneration. Int J Periodontics Restorative Dent. 2012 Feb;32(1):49-58

9. McGuire MK, Scheyer ET. A randomized, double-blind, placebocontrolled study to determine the safety and efficacy of cultured and expanded autologous fibroblast injections for the treatment of interdental papillary insufficiency associated with the papilla priming procedure. J Periodontol. 2007 Jan;78(1):4-17.

10. Becker W, Gabitov I, Stepanov M, Kois J, Smidt A, Becker BE. Minimally invasive treatment for papillae deficiencies in the esthetic zone: a pilot study. Clin Implant Dent Relat Res. 2010 Mar;12(1):1-8.

11. Sadat Mansouri S, Ghasemi M, Salmani Z, Shams N. Clinical Application of Hyaluronic Acid Gel for Reconstruction of Interdental Papilla at the Esthetic zone. The Journal of Islamic Dental Association of IRAN (JIDA). 2013;25(2):191-6.

12. Awartani FA, Tatakis DN. Interdental papilla loss: treatment by hyaluronic acid gel injection: a case series. Clin Oral Investig. 2016 Sep;20(7):1775-80.

13. Lee WP, Kim HJ, Yu SJ, Kim BO. Six Month Clinical Evaluation of Interdental Papilla Reconstruction with Injectable Hyaluronic Acid Gel Using an Image Analysis System. J Esthet Restor Dent. 2016 Jul;28(4):221-30.

14. Lee WP, Seo YS, Kim HJ, Yu SJ, Kim BO. The association between radiographic embrasure morphology and interdental papilla reconstruction using injectable hyaluronic acid gel. J Periodontal Implant Sci. 2016 Aug;46(4):277-87.

15. Nordland WP, Tarnow DP. A classification system for loss of papillary height. J Periodontol. 1998 Oct;69(10):1124-6.

16. Brochure of Naturelize Hyaluronic acid Products for Dentistry [press release]. 2012

17. Xue GP, McIntyre CL, Jenkins CL, Glassop D, van Herwaarden AF, Shorter R. Molecular dissection of variation in carbohydrate metabolism related to water-soluble carbohydrate accumulation in stems of wheat. Plant Physiol. 1998 Oct;69(10):1124-6.

18. Mayol L, Biondi M, Russo L, Malle BM, Schwach-Abdellaoui K, Borzacchiello A. Amphiphilic hyaluronic acid derivatives toward the design of micelles for the sustained delivery of hydrophobic drugs. Carbohydr Polym. 2014 Feb 15;102:110-6.

19. Jeong HY, Choi YS, Lee JK, Lee BJ, Kim WK, Kang H. Anti-Inflammatory Activity of Citric Acid-Treated Wheat Germ Extract in Lipopolysaccharide-Stimulated Macrophages. Nutrients. 2017 Jul 10;9(7):730.

20. Ahsan H, Ahad A, Iqbal J, Siddiqui WA. Pharmacological potential of tocotrienols: a review. Nutr Metab (Lond). 2014 Nov $12 ; 11(1): 52$.

21. Talaei-Khozani T, Monsefi M, Ghasemi M. Lectins influence chondrogenesis and osteogenesis in limb bud mesenchymal cells. 2011 Feb;28(2):89-98.

22. Teuschl AH, Neutsch L, Monforte X, Runzler D, van Griensven M, Gabor F, et al. Enhanced cell adhesion on silk fibroin via lectin surface modification. Acta Biomater. 2014 Jun;10(6):2506-17.
23. Guillaume O, Park J, Monforte X, Gruber-Blum S, Redl H, Petter-Puchner A, et al. Fabrication of silk mesh with enhanced cytocompatibility: preliminary in vitro investigation toward cellbased therapy for hernia repair. J Mater Sci Mater Med. 2016 Feb;27(2):37.

24. Gumus ZP, Guler E, Demir B, Barlas FB, Yavuz M, Colpankan D, et al. Herbal infusions of black seed and wheat germ oil: Their chemical profiles, in vitro bio-investigations and effective formulations as Phyto-Nanoemulsions. Colloids Surf B Biointerfaces. 2015 Sep 1;133:73-80.

25. Kim YS, Kong WH, Kim H, Hahn SK. Targeted systemic mesenchymal stem cell delivery using hyaluronate - wheat germ agglutinin conjugate. Biomaterials. 2016 Nov;106:217-27.

26. Schneider CA, Rasband WS, Eliceiri KW. NIH Image to ImageJ: 25 years of image analysis. Nat Methods. 2012 Jul;9(7):671-5.

27. Bertl K, Bruckmann C, Isberg PE, Klinge B, Gotfredsen K, Stavropoulos A. Hyaluronan in non-surgical and surgical periodontal therapy: a systematic review. J Clin Periodontol. 2015 Mar;42(3):236-46.

28. Sudha PN, Rose MH. Beneficial effects of hyaluronic acid. Adv Food Nutr Res. 2014;72:137-176.

29. Bowman EN, Hallock JD, Throckmorton TW, Azar FM. Hyaluronic acid injections for osteoarthritis of the knee: predictors of successful treatment. Int Orthop. 2018 Apr;42(4):733-740.

30. Brandt FS, Cazzaniga A. Hyaluronic acid gel fillers in the management of facial aging. Clin Interv Aging. 2008;3(1):153-9.

31. Keen MA. Hyaluronic Acid in Dermatology. Skinmed. 2017 Dec $1 ; 15(6): 441-448$

32. Voigt J, Driver VR. Hyaluronic acid derivatives and their healing effect on burns, epithelial surgical wounds, and chronic wounds: a systematic review and meta-analysis of randomized controlled trials. Wound Repair Regen. May-Jun 2012;20(3):317-31.

33. Tiwari S, Patil R, Bahadur P. Polysaccharide Based Scaffolds for Soft Tissue Engineering Applications. Polymers (Basel). 2018 Dec 20;11(1):1.

34. Lam J, Truong NF, Segura T. Design of cell-matrix interactions in hyaluronic acid hydrogel scaffolds. Acta Biomater. 2014 Apr;10(4):1571-1580.

35. Serban MA, Skardal A. Hyaluronan chemistries for three-dimensional matrix applications. Matrix Biol. 2019 May;78-79:337-345.

36. Casale M, Moffa A, Vella P, Sabatino L, Capuano F, Salvinelli B, et al. Hyaluronic acid: Perspectives in dentistry. A systematic review. Int J Immunopathol Pharmacol. 2016 Dec;29(4):572-582

37. Jentsch H, Pomowski R, Kundt G, Gocke R. Treatment of gingivitis with hyaluronan. J Clin Periodontol. 2003;30(2):159-64.

38. Johannsen A, Tellefsen M, Wikesjo U, Johannsen G. Local delivery of hyaluronan as an adjunct to scaling and root planing in the treatment of chronic periodontitis. J Periodontol. 2009 Sep;80(9):1493-7.

39. Polepalle T, Srinivas M, Swamy N, Aluru S, Chakrapani S, Chowdary BA. Local delivery of hyaluronan $0.8 \%$ as an adjunct to scaling and root planing in the treatment of chronic periodontitis: $A$ clinical and microbiological study. J Indian Soc Periodontol. JanFeb 2015;19(1):37-42.

40. Galli F, Zuffetti F, Capelli M, Fumagalli L, Parenti A, Testori T, et al. Hyaluronic acid to improve healing of surgical incisions in the oral cavity: a pilot multicentre placebo-controlled randomised clinical trial. Eur J Oral Implantol. Autumn 2008;1(3):199-206.

41. Lee JH, Jung JY, Bang D. The efficacy of topical $0.2 \%$ hyaluronic acid gel on recurrent oral ulcers: comparison between recurrent aphthous ulcers and the oral ulcers of Behcet's disease. J Eur Acad Dermatol Venereol. 2008 May;22(5):590-5.

42. Goiato MC, da Silva EV, de Medeiros RA, Turcio KH, Dos Santos DM. Are intra-articular injections of hyaluronic acid effective for the treatment of temporomandibular disorders? A systematic review. Int J Oral Maxillofac Surg. 2016 Dec;45(12):1531-1537.

43. FDA. Recently-Approved Devices: TRILURONTM - P180040. 2019.

44. Bertl K, Gotfredsen K, Jensen SS, Bruckmann C, Stavropoulos A. Can hyaluronan injections augment deficient papillae at implantsupported crowns in the anterior maxilla? A randomized controlled clinical trial with 6 months follow-up. Clin Oral Implants Res. 2017 Sep;28(9):1054-1061. 